\title{
A Study on the Knowledge Level and Extent of Adoption of Plant Protection Measures against Blast Disease of Rice by the Farmers of Indian Sundarbans
}

\author{
Sabita Nath ${ }^{1}$, Bholanath Mondal ${ }^{1 *}$ and Palash Mondal ${ }^{2}$ \\ ${ }^{1}$ Department of Plant Pathology, Palli Siksha Bhavana (Institute of Agriculture), Visva Bharati, \\ Sriniketan - 731 236, West Bengal, India. \\ ${ }^{2}$ Department of Agricultural Entomology, Palli Siksha Bhavana (Institute of Agriculture), Visva Bharati, \\ Sriniketan - 731 236, West Bengal, India.
}

Authors' contributions

This work was carried out in collaboration among all authors. Author SN performed the statistical analysis and wrote the first draft of the manuscript. Authors BM and PM designed the study, wrote the

protocol and managed the analyses of the study. Author SN managed the literature searches. All authors read and approved the final manuscript.

Article Information

DOI: 10.9734/ARRB/2020/v35i1230314
Editor(s):
(1) Paola Angelini, University of Perugia, Italy.
Reviewers:

(1) Zahoor Ahmad Bhat, SKUAST, India.

(2) Florin Imbrea, Banat University of Agricultural Sciences and Veterinary Medicine, Romania. Complete Peer review History: http://www.sdiarticle4.com/review-history/63156

Original Research Article

Received 02 October 2020

Accepted 07 December 2020

Published 21 December 2020

\begin{abstract}
The study was conducted to know the knowledge and adoption level of plant protection measures against blast disease among 80 respondent paddy growers in the blocks of North and South 24 Parganas of Sundarbans. About $48.75 \%$ of the respondents had medium knowledge. Majority of the respondents $(75 \%)$ knew about blast disease of rice and its key identifying symptom. The $67.5 \%$ farmers were having the knowledge about the fungicides used against the disease (Tricyclazole 75 WP, Carbendazim 50 WP, Hexaconazole 5EC), and $22.5 \%$ of the farmers knowing about the recommended dose of fungicide application. The $28.75 \%$ of the respondents also knew that the fungicide should be applied at the first appearance of the disease. Further, it has been found that the adoption level of plant protection measures against blast disease of rice was medium $(47.5 \%)$. Nearly $53.75 \%$ of the respondents practicing rice cultivation were in the middle age group
\end{abstract}


of 31-50 years. Most of the respondent had either $0.13-0.27$ ha (22.5\%) or $0.40-0.67$ ha $(37.5 \%)$ landholding wherein they were practicing rice cultivation. Almost all the respondents $(100 \%)$ possessed Knapsack or hand sprayer for fungicide application. Climatic vagaries, lack of knowledge about to the number of sprays and concerning technology application, non-availability of fungicide on time, lack of facility at the nearby place were the major constraints as expressed by $95,83.75,85,90$, and 95 per cent of respondents, respectively. The high cost of chemicals and expensiveness and non-availability of labour during peak cropping period were also the major constraints as expressed by 60 and 83.75 per cent of the respondents, respectively. There was a significant relationship between age, education, landholding, social, mass media and participation in extension activities with knowledge and adoption levels of the farmers of the Indian Sundarbans.

Keywords: Adoption level; blast disease; knowledge level; plant protection measures; rice; Sundarbans.

\section{INTRODUCTION}

Rice, as a cereal grain, is the staple food for a large part of the world's human population including more than 100 countries worldwide [1]. It is anticipated that the rice consumption around the world will continue to grow steadily at around $1.1 \%$ per annum according to a report published by market research firm IndexBo. The rice production in India was 172.8 million metric tons in 2018 and is projected to register a CAGR of $2.7 \%$ during the forecast period, 2020-2025 [2]. Major Rice producing states in India are West Bengal, Uttar Pradesh, Andhra Pradesh, Punjab, Tamil Nadu, Odisha, and Bihar. West Bengal is the largest producer of Rice in India. The total production of rice during 2017-18 was 14.97 million tonnes with a share of $13.26 \%$ in all India production [3].

Sundarbans, the southern-most part of West Bengal under Coastal and Saline agro-ecological zone is the largest delta on planet Earth. The livelihoods of the rural people in Sundarbans are predominantly dependent on agriculture, which occupies a substantial proportion of the land area. The agrarian economy of Sundarbans is primarily dominated by rice-based farming system, where generally the rice-rice-fallow system is being practiced year after year. There are many constraints such as salinity, impeded drainage, lack of irrigation potential, lack of proper communication for marketing of produce etc. Besides, most of the areas are monocropped with rice. Sustainable agriculture is an essential component of economic growth which ultimately seeks to sustain farmers, resources and communities by promoting farming practices and techniques that are economically viable, environmentally sound and socially supportive. The economic growth and progress actually depend to a large extent on the improvement of agricultural technology and the adoption of agricultural innovations by the farmers. Therefore, it is necessary to change the attitude of the farmers so that they may shift from traditional to modern methods of farming. For this purpose, it is essential to disseminate the useful technical know-how from lab to land to the millions of farmers.

The farmers should be kept abreast with the latest technological innovation in the field of agriculture and subsequent motivation through aggressive extension activities towards the adoption of new technologies and modern farm practices. Their knowledge and experience also help them or compel them to adopt new technologies to keep agricultural practices ongoing and to maintain their livelihood properly. With burgeoning population and pressure on limited land resource, the need of the hour is to increase the production and productivity of crop to mitigate poverty, hunger and malnutrition. In order to increase the production and productivity of crop, it is quite evident that every effort should be drawn towards the enhancement of adoption of improved farm practices to its greatest level. The prerequisite to the adoption process is the knowledge of the recommended technologies. The basic input for achieving higher productivity through the assimilation of technological knowledge is one of the important components of behaviour and as such, it plays a major role in covert and overt behaviour of human beings. Knowledge of technology is the basic requirement as it gives impetus to adopt the technology. The adoption of any technologies depends on the individual development and acceptance of modern agricultural technology is the prime attention for increasing crop production. It is generally observed that all the farmers do not use recommended practices. It is the experience of the extension workers that 
many practices including plant protection measures in spite of their merits are not being accepted widely by the farmers. Some technologies record very slow rate of adoption. It is, therefore, a question as to why one practice is more readily adopted than the other. One of the possible answers is some innate characteristics of the practice, which may speed up or retard its rate of adoption. The differential rate of adoption of farm technologies by the farmers is generally attributed to some of the personal and socioeconomic characteristics of farmers [4].

Rice blast is responsible for yield losses of about $10 \%$ to $30 \%$ annually ([5], [6], [7]). Under favourable environmental conditions, it can cause havoc to the entire rice crop within 15 to 20 days and cause yield losses of up to $100 \%$ [8]. Thus, it poses a crucial challenge to rice production thereby threatening global food security. In Sundarbans, blast disease in rice is one of the important diseases. Plant protection measures for the management of blast disease of rice plays a vital role in modern agriculture. Fertilizers, plant protection measures, irrigation and improved seeds are the key elements of modern agriculture. In the absence of adequate plant protection measures, the positive contribution of improved seeds, fertilizers and irrigation to output could completely nullify and farmers may incur heavy losses. Thus, in this perspective, the study was undertaken to know the knowledge and adoption level of different plant protection measures for the management of blast disease of rice by the farmers of the Sundarban region.

\section{MATERIALS AND METHODS}

The study was conducted in the randomly selected villages in the blocks of North and South 24 Parganas of Sundarbans to know the knowledge and adoption level of plant protection measures for the management of blast disease of rice. Four villages namely Hiranmyapur (Basanti CD block), Kachukhali (Gosaba CD block), Jogeshganj (Hingalganj CD block), Radhanagar (Sahara Radhanagar) (Sandeshkhali I CD block) were selected during 2016-17. These villages were purposively selected since these villages were dominated by rice based farming system and also based on the criteria of blast diseases incidence level. In each selected village, list of farmers cultivating rice crop during 2016-17 was prepared and from each village 20 farmers were selected randomly. Thus, 80 paddy growing farmers spread over four villages of Sundarbans constituted the total sample size for the study. Based on the objectives, variables and available literature on the topic an interview schedule was prepared in English language taking into consideration that questions do not include ambiguous and contradictory statements. In this way the research schedule was constructed to collect the necessary information. The author personally interviewed the respondents included in the sample. The importance and objectives of the study were clearly explained to all the respondents. They were assured that all the information furnished by them will be used for the research study only. The qualitative data was quantified by using various statistical tools and working out different scores in order to find out the nature of association between dependent and independent variables.

\subsection{Independent Variables}

\subsubsection{Age}

It is one of the basic characteristic of an individual linked with his maturity, physical fitness and productivity. At the time of interview, chronological age was considered as it is a convenient and often very good predictor of health status, disease burden and physical capability. The respondents according to age were classified into three categories.

a. Up to 30 years - Young

b. 31 to 50 years - Middle Age

c. 50 years and above - Old Age

\subsubsection{Education}

The level of formal education attained by an individual tends to influence the extent to which an individual is exposed to new ideas and outer world. According to formal education, the respondents were classified into following categories.
a. Upto 8th class
b. 89 th to Higher secondary
c. Graduate and above

\subsubsection{Land holding}

The land holding refers to the actual land owned by the family of farmers in bigha ( 1 bigha $=33$ decimal) that was converted into hectare (ha). According to the extent of land possessed by them, the respondents were classified into five categories. 

a. Upto 0.13ha
b. $0.13-0.40 \mathrm{ha}$
c. $0.40-0.67 \mathrm{ha}$
d. $0.67-1.33 \mathrm{ha}$
e. Above 1.33ha

\subsubsection{Source of irrigation}

The source of irrigation is operationalised as the number of source of irrigation possessed by an individual farmer. The score was worked out by assigning one score to shallow pumps, two score to stored rain water in the ponds and score three to canal (khal) - big water bodies. Frequency and percentages were used to present the data.

\section{Shallow pumps}

2. Stored rain water in the ponds

3. Canal (Khal)- Big Water Bodies

\subsubsection{Possession of plant protection equipments}

The possession of plant protection equipments is operationalized as the number of plant protection equipments owned by an individual farmer. The score was worked out by assigning one score to each respondent having participation in one social organization and zero score was assigned to the respondent with no participation. Frequency and percentages were used to present the data. The plant protection equipments taken into consideration were:
a. Knapsack Sprayers
b. Foot sprayers
c. Power sprayers
d. Weighting machines
e. Measuring cylinder/cap
f. Duster

\subsubsection{Social participation}

Social participation refers to the participation of a respondent in various formal and informal organizations. The different social media sources were listed and the respondents were asked to indicate their participation in each of these activities. The score was worked out by assigning one score to each respondent for participation in one social organization score and zero score was assigned to the respondent with no participation. Frequency and percentages were used to present the data. The various social organizations considered were:

1. Village panchayat

2. NGO
3. Co-operative society/bank

4. Farmer's Club

\subsubsection{Mass media participation}

This refers to the exposure of an individual farmer to different mass media and the degree of participation in them. The different mass media sources were listed and the respondents were asked to indicate their participation in each of these activities. The score was worked out by assigning one score to each respondent for utilizing one mass media and zero score was assigned to the respondent with no utilization of mass media. Frequency and percentages were used to present the data. The various mass media considered were:

1. Reading / Listening newspaper

2. Listening to radio (agricultural programmes)

3. Farm magazines/ leaflets

4. Television

\subsubsection{Extension participation}

It refers to the extent of participation of the farmers in different extension activities conducted during the year 2016-17 in the area. A list of extension activities was prepared and respondents were asked to indicate their participation in each one of them. The score was worked out by assigning one score to each respondent for participation in one extension activity and zero score was assigned to the respondent with no participation in extension activity. Frequency and percentages were used to present the data. The various extension activities considered were:

1. Participation in demonstrations

2. Participation in extension meetings with ADA, Panchayat, Cooperative society, Companies, NGO

3. Participation in field days on farmer's field

4. Participation in Krishimela / Kisan mela / Agricultural fair

\subsection{Dependent Variables}

\subsubsection{Knowledge}

This refers to the farmers understanding or the body of information understood and retained by the farmers about recommended plant protection measures in rice cultivation. In this study, all the important plant protection measures for 
management of blast disease of rice were listed in consultation with the experts in this field. A total number of 21 common recommended plant protection measures in rice crop were selected based on the judgment of specialists. The relevant answers for these items were obtained with the help of package of practices and paddy crop experts of the Visva-Bharati, Palli-Shiska Bhavana, Department of Plant Pathology. Each correct knowledge item was credited with one score and zero score was given to wrong answer. Thus, the maximum score that one could get was 21 and the minimum being zero. The total knowledge score for each respondent was calculated by summing up the number of items correctly answered by an individual respondent. Based on the total scores obtained, the knowledge index was worked out as follows:

$$
\begin{aligned}
& \text { Knowledge index } \\
& =\frac{\text { Number of correct response }}{\text { Total number of knowledge items }} \times 100
\end{aligned}
$$

Respondents were further categorized into three groups of knowledge level based on Mean $(\bar{x})$ and Standard deviation (SD).

\subsubsection{Adoption}

Adoption is a mental process in which an individual passes from first hearing of an innovation to its final adoption. The term adoption in this study means the use of recommended plant protection measures against blast disease of rice for getting expected benefits. In this case, same procedures were followed for listing up the 17 recommended common plant protection measures for managing the blast disease of rice in consultation with the subject specialists. The relevant answers for these items were obtained with the help of package of practices and paddy crop experts. Each full adopted item was credited with two score, one score for the partially adopted item and zero score for non-adoption. Thus, the maximum score that one could get was 17 and the minimum being zero. The maximum and minimum scores obtained for each respondent were 17 and 0 . The total adoption score for each respondent was calculated by summing up the number of items correctly answered by an individual respondent. Based on the total scores obtained, the adoption index was worked out as follows:

$$
\begin{aligned}
& \text { Adoption quotient } \\
& =\frac{\text { Adoption score of respondent } \mathrm{x} 100}{\text { Maximum adoption score one could get }}
\end{aligned}
$$

\subsection{Statistical Analysis}

The data collected was processed, quantified, categorized and tabulated. The established parameters like mean, frequency, percentage and Karl Pearson's correlation coefficient were calculated.

\section{RESULTS AND DISCUSSION}

The data presented in Table 1 indicate that majority of the respondents $(53.75 \%)$ belonged to middle age group. Since, respondents between 31 to 50 years of age group are physically active and accordingly have the better physical capability, good vigour and also more responsibility towards family than the younger ones. This might be the important reason to find that majority of the respondents were in the age group of 31 to 50 years. The results are in line with the research findings reported by earlier workers ([9], [10] and [11]). Data presented in Table 1, further indicate that 20 per cent of

Chart 1. Categorized into three groups of knowledge level based on Mean $(\overline{\mathbf{x}})$ and Standard deviation (SD)

\begin{tabular}{lll}
\hline Category & Criteria & Mean score \\
\hline Low & $<\overline{\mathrm{x}}-1 / 2$ SD & $<35.87$ \\
Medium & $\overline{\mathrm{x}}-1 / 2$ SD to $\overline{\mathrm{x}}+1 / 2 \mathrm{SD}$ & $35.87-55.67$ \\
High & $<\overline{\mathrm{x}}+1 / 2$ SD & $>55.67$ \\
\hline
\end{tabular}

Chart 2. The respondents were categorized into three categories (low, medium, high) based on Mean ( $\bar{x})$ and Standard deviation (SD)

\begin{tabular}{lll}
\hline Category & Criteria & Mean score \\
Low & $<\bar{x}-1 / 2$ SD & $<25.81$ \\
Medium & $\bar{x}-1 / 2$ SD to $\bar{x}+1 / 2$ SD & $25.81-42.43$ \\
High & $<\bar{x}+1 / 2 S D$ & $>42.43$ \\
\hline
\end{tabular}


the respondents have received education upto $8^{\text {th }}$ class, 35 per cent upto higher secondary and 45 per cent were graduates and above. The literacy rate has improved lot because of the impetus provided by various government schemes to arrest school dropout rates. Since, literacy is the key to socio-economic progress, so parents in order to improve the future prospect of their children have come in the way of getting them better education. The results revealed that the land holders in the category of $0.13-0.67$ ha was more $(37.5 \%)$, followed by $0.13-0.40$ ha category $(22.5 \%)$, upto 0.13 ha $(18.75 \%), 0.67-$ 1.33ha (15\%) and above 1.33ha (6.25\%). The possible reason for low land holdings might be that the ancestor land was fragmented into smaller and smaller sized land holdings. Further, climate change is triggering a silent yet drastic livelihood changes in the agricultural fields and water bodies of Sundarbans. As agriculture and fishing become increasingly unviable in the island conglomerate battered by extreme weather events and salt water ingression, a sizeable number of farmers are turning into migrant labours or are forced to work in the hundreds of brick kilns that have mushroomed on both sides of the border. These farmers, earlier tending to crops and fishes, are now finding refuge in construction and mining jobs in faraway in the Indian states of Kerala, Gujarat, Karnataka and Maharashtra. In spite of having a fewer acres of land holding, they did not find sufficient time to devote to agriculture because of engagement into occupations other than agriculture. Perusal of Table 1 reveals that almost all the farmers possessed kanpsack sprayer and measuring cylinder/cap (100\%) for fungicide application followed by possession of weighting machine $(15 \%)$, foot sprayers $(10 \%)$, power sprayers $(7.5 \%)$. None of them possessed duster. Most of the farmers used stored rain water in ponds $(71.25 \%)$ for irrigation followed by canal irrigation $(22.5 \%)$ or shallow pump (6.25\%).

The data presented in Table 2 indicate that $85 \%$ per cent of the respondents listened to radio as a source to get information followed by newspaper $(56.25 \%)$, farm magazines and television. Radio, the most popular mass media was possessed by majority of the respondent as it is portable less costly and without any strain to eyes. It has the power to create awareness and can make a difference in the lives of listeners. Nobody used mobile phone to gather information. These findings get support from the studies conducted by Raghavendra [12] and Lakshmisha [10], who reported that mass media considered as credible source of information by majority of the respondents studied.

Table 1. Socio-economic profile of paddy growers

\begin{tabular}{llll}
\hline Variables & Category & \multicolumn{2}{c}{ Respondents } \\
\cline { 3 - 4 } & & Frequency & Percentage \\
\hline 1.Age & Upto 30 years (Young) & 10 & 12.5 \\
& $31-50$ years (Middle) & 43 & 53.75 \\
& 50 years and above (Old) & 27 & 33.75 \\
\hline 2.Education & Upto 8th class & 16 & 20 \\
& 8th to Higher Secondary & 28 & 35 \\
& Graduate and above & 36 & 45 \\
\hline 3.Land holding & Upto 0.13ha & 15 & 18.75 \\
& $0.13-0.40$ ha & 18 & 22.5 \\
& $0.40-0.67 h a$ & 30 & 37.5 \\
& O.67 -1.33ha & 12 & 15 \\
\hline 4.Plant protection & Above 1.33ha & 5 & 6.25 \\
equipments & Knapsack Sprayers & 80 & 100 \\
possessed & Foot sprayers & 8 & 10 \\
& Power Sprayers & 6 & 7.5 \\
& Weighting machines & 12 & 15 \\
& Measuring cylinder/cap & 80 & 100 \\
\hline 5.Source of irrigation & Duster & 0 & 0 \\
& Shallow pump & 5 & 6.25 \\
& Stored rain water in the ponds & 57 & 71.25 \\
& Canal (Khal)- Big Water & 18 & 22.5 \\
& Bodies & & \\
\hline
\end{tabular}


The data presented in Table 2 indicate that majority of the respondents $(90 \%)$ participated in Krishimela, exhibitions to enrich their knowledge and for motivation. Besides, such exhibition gives the farmers much needed exposure to plethora of farm implements, different technologies, demonstration of a unique transplantation methods, demonstration on the mixed cropping system in horticulture, demonstration unit on duck and fisheries, exhibition on vermicompost containers, honeybee rearing and innovative methods of farming, especially cultivation of vegetables etc. Similarly, most of the respondents $(81.25 \%)$ also participated in field trips, extension meetings organized by ADA, Panchyat, cooperative society, different agrochemical companies, NGO for their benefit. The participation of the respondents in other activities was comparatively less because of lack of motivation and less interest. The results were in line with the findings of Nityashree and Siddaramaiah [13], whereas Balasubramani [14] found that the majority of the farmers' participation in extension activities was very low.

The data presented in Table 2 indicate majority of the farmers (87.5\%) were associated with Cooperative society/bank followed by fellow farmers $(68.5 \%)$ and NGO $(52.5 \%)$. For rest of the organization the association of the respondents was low. This implied that the participation in Cooperative society/bank was very high as compared to other selected organizations. This is because this organization plays a vital role in improving the economic and social condition. It offers short-term and medium-term loan to the members/farmers at sensible interest rates to meet their different needs. It offers credit to the farmers for agriculture function at cheap and simple terms.

The data presented in Table 3, Fig. 1 indicate that the $48.75 \%$ of the respondent had medium level, $27.5 \%$ low level and $23.75 \%$ high level of knowledge regarding recommended plant protection measures for management of blast disease of rice. Further, perusal of Table 4 revealed that $91.25 \%$ of the respondent knew the name of the blast disease of rice locally known as Jhalsa as this is one of the major diseases in rice in their area. Also, $75 \%$ of the respondents were aware of the key identifying symptom of blast disease of rice. About $67.5 \%$ of the respondent knew that for management of blast disease of rice, fungicides like Tricyclazole 75 WP (Beam) and Hexaconazole 5 EC (Sitara) are used but only $22.5 \%$ respondent knew about the recommended dose of these fungicides application for control of blast of rice. Also, 35\% of the respondent knew about seed treatment with fungicide for control of blast disease of rice. Few of the respondents also knew about the time and stage of the crop for fungicide application. Cultural practices like use of resistant variety, use of good quality disease free seeds, alteration in the time of transplanting date to skip the incidence of blast disease were known by few respondents especially by the farmers practicing SRI method of rice cultivation and those farmers who had 30-40 years of farming experience. Role of fertilizer in providing major $(\mathrm{N}, \mathrm{P}, \mathrm{K})$ and minor nutrients $(\mathrm{Zn}, \mathrm{Si})$ and subsequently their role in

Table 2. Farmers participation in various events

\begin{tabular}{llll}
\hline Participation type & & Respondents \\
& & $\begin{array}{l}\text { Frequency } \\
\text { Mass media }\end{array}$ & Percentage \\
\hline participation & Reading / Listening newspaper & 45 & 56.25 \\
& $\begin{array}{l}\text { Listening to radio (agricultural } \\
\text { programmes) }\end{array}$ & 68 & 85 \\
& Farm magazines/ leaflets & 34 & 42.5 \\
& Television & 20 & 25 \\
& Mobile & 0 & 0 \\
\hline Extension & Demonstrations & 16 & 20 \\
activities & Extension meetings by ADA, Panchyat, & 65 & 81.25 \\
& Cooperative society, Companies, NGO & & \\
& Farmers' Field days & 17 & 21.25 \\
& Krishimela /Exhibition & 72 & 90 \\
\hline Social activities & Village panchayat & 25 & 31.25 \\
& NGO & 42 & 52.5 \\
& Co-operative society/bank & 70 & 87.5 \\
& Farmer's Club & 23 & 28.75 \\
& Fellow farmers & 55 & 68.75 \\
\hline
\end{tabular}


blast disease management was also known by very few respondents. Indiscriminate use of nitrogenous fertilizer enhances the blast disease of rice where $\mathrm{Zn}$ and $\mathrm{Si}$ were found to prevent the blast disease of rice. About $43.75 \%$ respondents had knowledge about the correct dose of fertilizer application. It is better to acquire knowledge in every practice as it enhances better adoption level. The findings were in conformity with the observations of Balasubramani [14] and Raghavendra [12].

The adoption of plant protection measures and ultimately its degree of success depends on various factors such as farmer's knowledge, situational factors, socio-psychological characteristics of farmers, the characteristics of innovation itself, complexity of practices, timely availability of inputs, relative advantage, compatibility etc. Further, these measures will be adopted more widely when it is considered superior to the alternative solution that it replaces. The relative advantage might be measured in economic terms also. The data presented in Table 5, Fig. 2 revealed that the adoption level of the plant protection measures for management of blast disease of rice by the respondents was medium in $47.5 \%$ respondents, low in $32.5 \%$ and high in $20.0 \%$. Further, the findings of the present study in Table 6 , revealed that considerable percentage $(46.25 \%)$ of the paddy growers have fully adopted plant protection measures like use of fungicides Tricyclazole 75 WP, Carbendazim 50 WP, Hexaconazole $5 \mathrm{EC}$ for control of blast disease of Rice whereas $21.2 \%$ adopted partially. However, very low percentage $(12.5 \%)$ of the paddy growers adopted fully the recommended dose of fungicides application for blast disease control and $10 \%$ adopted partially. Only $5 \%$ of the paddy growers applied fungicides either in the morning or evening when the air drift is low and $6 \%$ of the paddy growers used the recommended method of fungicide application, first at 15 days interval and subsequent spraying at 15-21 days interval depending upon the severity of the disease. None of the paddy growers used resistant variety, nor used quality seed free from disease; neither used seed treatment for management of blast disease of rice. Full adoption of recommended dose of fertilizer was very low (8.75\%) which is otherwise very important for blast disease management as recommended dose is directly proportional to judicious use of nitrogenous fertilizer. Only 35\% of the respondent have adopted partially. Further, application of $\mathrm{Zn}$ and silicon based fertilizer plays a significant role in management of blast disease of rice but it has been found that very few respondent $(6.25 \%)$ have applied zinc fertilizer as cheated zinc at recommended dose whereas $12.5 \%$ of the respondent have adopted this practice partially. It has been found that none of the farmers were aware about the role of silicon in blast disease management in rice and thus have also not applied any form of fertilizer or any source containing $\mathrm{Si}$ in rice cultivation. Due to various reasons like non-availability of plant protection inputs, lack of technical knowledge regarding plant protection etc. the adoption of plant protection measures was low. The findings of the study were in accordance with the results of Vasanthakumar [15] and Manjunath [16].

The results presented in Table 7 revealed the relationship of independent variables with knowledge level of the respondents about plant protection measures against blast disease of rice. The variables such as age, land holdings, possession of plant protection equipments, participation in extension activities and mass media utilization exhibited positively significant relationship at $1 \%$ level of significance with the knowledge level of plant protection measures against rice blast disease. The variables like source of irrigation and social participation showed non-significant relationship with knowledge level with respect to plant protection measures of paddy crop in particular against blast disease. It has been found that the independent variable education exhibited negative significant relationship with the knowledge level of plant protection measures against blast disease of rice. The younger

Table 3. Knowledge level of the respondents about recommended plant protection measures for management of blast disease of rice

\begin{tabular}{llll}
\hline Knowledge level & Frequency & Percentage & $(\mathbf{n}=\mathbf{8 0})$ \\
\hline Low $(<35.87)$ & 22 & 27.5 \\
Medium $(35.87-55.67)$ & 39 & 48.75 \\
High $(>55.67)$ & 19 & 23.75 \\
Total & 80 & 100 \\
\hline
\end{tabular}




\section{KNOWLEDGE LEVEL}

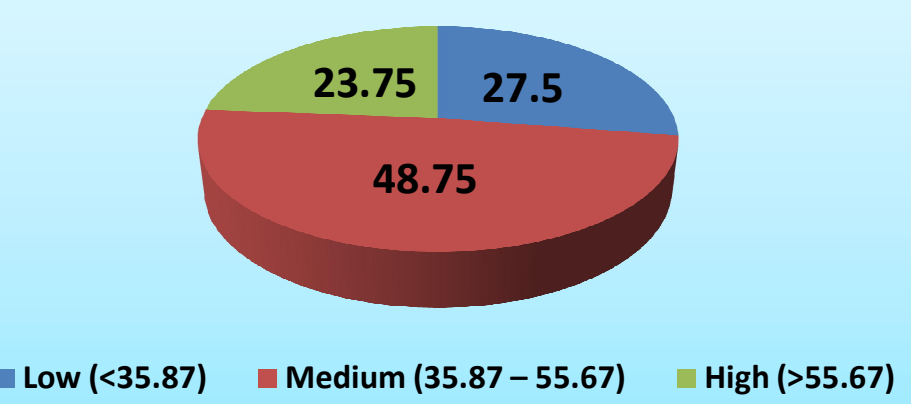

Fig. 1. Knowledge level of the farmers of Sundarbans about the plant protection measures for management of blast disease of rice

Table 4. Knowledge of individual component of blast disease management practices in rice cultivation

\begin{tabular}{|c|c|c|c|}
\hline SI. no. & Knowledge level & Frequency & Percentage \\
\hline 1. & Disease Resistant Varieties & 2 & 2.5 \\
\hline \multicolumn{4}{|c|}{ Nursery raising techniques } \\
\hline 2. & Good quality seeds free from diseases & 25 & 31.25 \\
\hline 3. & Seed Treatments for blast disease & 28 & 35 \\
\hline 4. & Recommended dose for seed treatment & 10 & 12.5 \\
\hline 5. & Recommended time of seed sowing in seed bed & 80 & 100 \\
\hline \multicolumn{4}{|c|}{ Seedling transplantation } \\
\hline 6. & Alternation of transplanting date to overcome blast disease & 15 & 18.75 \\
\hline 7 & Number of seedlings per hill & & \\
\hline a & 5-7 seedlings/hill & 29 & 36.25 \\
\hline b & 3-4 seedlings/hill & 46 & 57.5 \\
\hline c & 1-2 seedlings/hill & 5 & 6.25 \\
\hline 8 & Recommended Spacing & 57 & 71.25 \\
\hline 9 & $\begin{array}{l}\text { Water Management: Maintenance of water level in } \\
\text { transplanted field } \\
\text { Farm yard manure application }\end{array}$ & 23 & 28.75 \\
\hline 10 & Quantity and Quality of FYM (Rate/ha) & 8 & 10 \\
\hline 11 & Time \& Method of applying FYM & 78 & 97.5 \\
\hline \multicolumn{4}{|c|}{ Chemical fertilizers } \\
\hline 12 & Recommended Quantity/rate of chemical fertilizers application & 35 & 43.75 \\
\hline 13 & Method of application & 35 & 43.75 \\
\hline 14 & Micronutrient Zinc application & 21 & 26.25 \\
\hline 15 & Silicon fertilizer application & 0 & 0 \\
\hline 16 & Names of diseases -Blast of rice (Jhalsa) & 73 & 91.25 \\
\hline 17 & Key Identifying Symptom -Blast of rice & 60 & 75 \\
\hline 18 & $\begin{array}{l}\text { Fungicides for Blast of Rice (Tricyclazole } 75 \% \text { WP, } \\
\text { Carbendazim } 50 \text { WP, Hexaconazole } 5 \% \text { EC) }\end{array}$ & 54 & 67.5 \\
\hline 19 & Recommended Dose - Blast disease of Rice & 18 & 22.5 \\
\hline 20 & Time of spraying of fungicide (Morning/evening) & 7 & 8.75 \\
\hline 21 & Stage of application of fungicide & & \\
\hline a & At first appearance of disease & 23 & 28.75 \\
\hline $\mathrm{b}$ & $\begin{array}{l}\text { At First appearance and at } 15 \text { days interval after first } \\
\text { appearance depending upon severity of disease }\end{array}$ & 10 & 12.5 \\
\hline c & $2-3$ times throughout the cropping season & 29 & 36.25 \\
\hline
\end{tabular}


Table 5. Adoption level of the respondents about plant protection measures against blast disease in rice cultivation

\begin{tabular}{lll} 
& & \\
\hline Adoption level & Frequency & Percentage \\
\hline Low $(<25.81)$ & 26 & 32.5 \\
Medium $(25.81-42.43)$ & 38 & 47.5 \\
High $(>42.43)$ & 16 & 20.0 \\
Total & 80 & 100 \\
\hline \multicolumn{2}{c}{ Mean $=34.12 \quad S D=16.62$} \\
\end{tabular}

Table 6. Extent of adoption of important plant protection measures against blast disease of rice

\begin{tabular}{|c|c|c|c|c|c|c|c|}
\hline \multirow{3}{*}{$\begin{array}{l}\text { S. } \\
\text { no. }\end{array}$} & \multirow[t]{3}{*}{ Plant protection practices } & \multicolumn{4}{|c|}{ Adoption level of respondents } & \multirow{2}{*}{\multicolumn{2}{|c|}{$\begin{array}{r}\mathrm{n}=80 \\
\text { Non adoption }\end{array}$}} \\
\hline & & \multicolumn{2}{|c|}{ Full adoption } & \multicolumn{2}{|c|}{ Partial adoption } & & \\
\hline & & Frequency & $\%$ & Frequency & $\%$ & Frequency & $\%$ \\
\hline 1. & Disease Resistant Variety & 0 & 0 & 0 & 0 & 80 & 100 \\
\hline 2. & $\begin{array}{l}\text { Good quality seeds free from } \\
\text { disease }\end{array}$ & 0 & 0 & 22 & 27.5 & 58 & 72.5 \\
\hline 3. & Seed Treatments & 0 & 0 & 12 & 15 & 68 & 85 \\
\hline 4. & $\begin{array}{l}\text { Recommended dose for seed } \\
\text { treatment }\end{array}$ & 0 & 0 & 7 & $\begin{array}{l}8.7 \\
5\end{array}$ & 73 & $\begin{array}{l}91.2 \\
5\end{array}$ \\
\hline 5. & $\begin{array}{l}\text { Recommended time of seed } \\
\text { sowing in seed bed }\end{array}$ & 80 & 100 & 0 & 0 & 0 & 0 \\
\hline 6 & $\begin{array}{l}\text { Alternation of transplanting } \\
\text { date to overcome incidence } \\
\text { of blast disease of Rice }\end{array}$ & 0 & 0 & 0 & 0 & 80 & 100 \\
\hline 7 & Recommended seedlings/hills & & & & & & \\
\hline$a$ & 3-4 seedlings/hill & 46 & 57.5 & 0 & 0 & 34 & 42.5 \\
\hline $\mathrm{b}$ & 1-2 seedlings/hill & 5 & 6.25 & 0 & 0 & 75 & 93.75 \\
\hline 8 & Recommended Spacing & 28 & 35 & 11 & 13.75 & 41 & $\begin{array}{l}51.2 \\
5\end{array}$ \\
\hline 9 & $\begin{array}{l}\text { Water Management: } \\
\text { Maintenance of water level in } \\
\text { transplanted field }\end{array}$ & 0 & 0 & 0 & 0 & 0 & 0 \\
\hline 10 & $\begin{array}{l}\text { Quality, Quantity and } \\
\text { method of application of } \\
\text { FYM }\end{array}$ & 6 & 7.5 & 67 & 83.75 & 7 & 8.75 \\
\hline 11 & $\begin{array}{l}\text { Recommended Quantity and } \\
\text { method of chemical fertilizers } \\
\text { application }\end{array}$ & 7 & 8.75 & 28 & 35 & 45 & 56.25 \\
\hline 12 & $\begin{array}{l}\text { Micro nutrient Zinc } \\
\text { application }\end{array}$ & 5 & 6.25 & 10 & $\begin{array}{l}12 . \\
5\end{array}$ & 65 & 81.25 \\
\hline 13 & Silicon fertilizer application & 0 & 0 & 0 & 0 & 0 & 0 \\
\hline 14 & $\begin{array}{l}\text { Use of fungicides against } \\
\text { Blast of Rice (Tricyclazole } \\
75 \% \text { WP, Carbendazim 50\% } \\
\text { WP, Hexaconazole } 5 \% \text { EC) }\end{array}$ & 37 & 46.25 & 17 & 21.25 & 26 & 32.5 \\
\hline 15 & $\begin{array}{l}\text { Recommended dose of } \\
\text { Fungicide against Blast } \\
\text { disease of Rice }\end{array}$ & 10 & 12.5 & 8 & 10 & 62 & 77.5 \\
\hline 16 & $\begin{array}{l}\text { Time of spraying of fungicide } \\
\text { (Morning/evening) }\end{array}$ & 5 & 6.25 & 2 & 2.5 & 73 & 91.25 \\
\hline 17 & $\begin{array}{l}\text { Recommended method of } \\
\text { application of fungicide } \\
\text { against blast of rice. }\end{array}$ & 6 & 7.5 & 14 & 17.5 & 60 & 75 \\
\hline
\end{tabular}




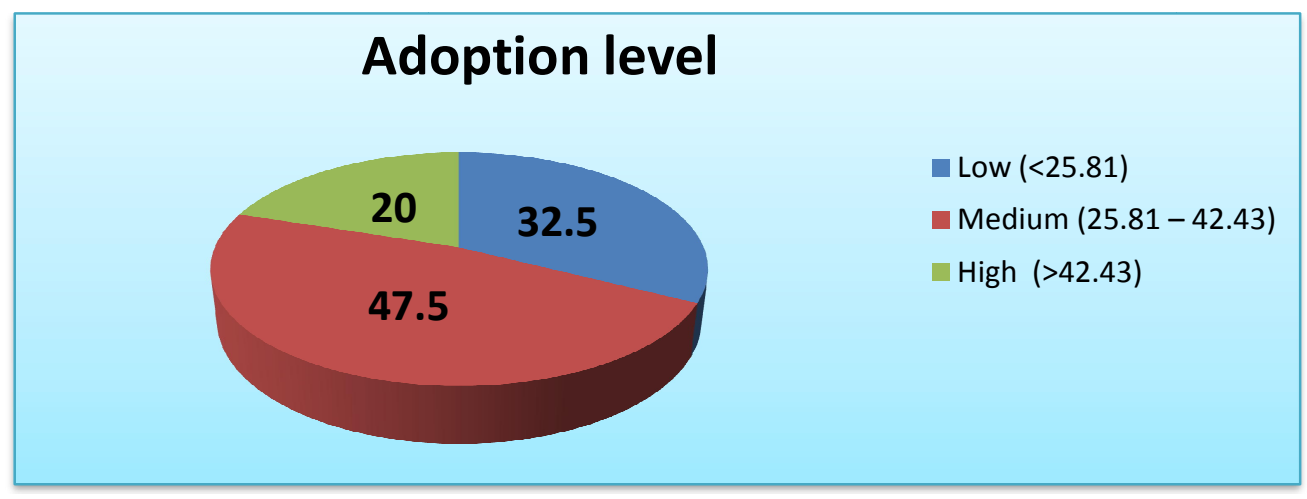

Fig. 2. Adoption level of the farmers of Sundarbans about the plant protection measures for management of blast disease of rice

Table 7. Relationship between selected socio-psychological characteristics of paddy growers and their knowledge level of plant protection measures against blast disease of rice

\begin{tabular}{|c|c|c|}
\hline Sl. no. & Socio-psychological characteristics & Karl Pearson's value \\
\hline 1 & Age & $0.459^{* *}$ \\
\hline 2 & Education & $-0.329^{\star *}$ \\
\hline 3 & Land holding & $0.403^{* *}$ \\
\hline 4 & Possession of Plant Protection equipment & $0.358^{* *}$ \\
\hline 5 & Sources of irrigation & 0.148 \\
\hline 6 & Social participation & 0.107 \\
\hline 7 & Mass media participation & $0.291^{\star \star}$ \\
\hline 8 & Extension Participation & $0.353^{\star *}$ \\
\hline
\end{tabular}

generation with high level of education level are least interested in the field work due to their perception that farming is antiquated and unprofitable profession. The image of agriculture traditionally has been more about subsistence; you produce enough for you to eat.

The results presented in Table 8 revealed the relationship of independent variables with adoption level of the respondents about plant protection measures against blast diseases of rice crop. The variables such as age, land holding and participation in extension activities exhibited positive and significant relationship with the adoption level of plant protection measures against blast disease of rice at $1 \%$ level of significance whereas possession of plant protection equipments, mass media and social participation had significant and positive corelation with adoption level at $5 \%$ level of significance. However, the variable education, exhibited negative and significant correlation. The variable, source of irrigation, showed nonsignificant relationship with adoption level of plant protection measure against blast disease in rice crop.

Table 8. Relationship between selected socio-psychological characteristics of paddy growers and their adoption level of plant protection measures of paddy crop

\begin{tabular}{lll}
\hline Sl. no. & Socio-psychological characteristics & Karl Pearson's value \\
\hline 1 & Age & $0.350^{*}$ \\
2 & Education & $-0.221^{*}$ \\
3 & Land holding & $0.303^{* *}$ \\
4 & Possession of Plant Protection equipment & $0.277^{*}$ \\
5 & Sources of irrigation & 0.171 \\
6 & Social participation & $0.266^{*}$ \\
7 & Mass media participation & $0.246^{*}$ \\
8 & Extension Participation & $0.379^{* *}$ \\
\hline & ${ }^{* *}$ Correlation is significant at the 0.01 level (2-tailed), ${ }^{*}$ Correlation is significant at the 0.05 level (2-tailed)
\end{tabular}


Table 9. Distribution of farmers according to the constraints faced by respondents in adoption of plant protection measures for management of blast disease of rice

\begin{tabular}{llll} 
& & & (n=80) \\
\hline SI. no. & Constraints & Frequency & Per cent \\
\hline 1 & Erratic rainfall, flood and submergence, lack of irrigation facilities & 76 & 95 \\
\hline 2 & Non availability of input on time due to problem of transport & 72 & 90 \\
\hline 3 & Lack of requiring facility at nearby places & 76 & 95 \\
\hline 4 & $\begin{array}{l}\text { Complicated name of chemicals or lack of knowledge about } \\
\text { chemicals }\end{array}$ & 78 & 97.5 \\
\hline 5 & Lack of knowledge with regard to technology application & 68 & 85 \\
\hline 6 & $\begin{array}{l}\text { Difficulty in disease management due to lack of knowledge } \\
\text { about number of spray }\end{array}$ & 67 & 83.75 \\
\hline 7 & High cost of farm inputs (like seed, fertilizers, pesticides etc.) \\
\hline 8 & $\begin{array}{l}\text { Lack of Finance due to illegal practices and bribery by govt. } \\
\text { officials for providing loans, services, subsidy etc. }\end{array}$ & 48 & 60 \\
\hline 9 & $\begin{array}{l}\text { Expensive labour and non-availability of labour during peak rice } \\
\text { season }\end{array}$ & 67 & 55 \\
\hline 10 & $\begin{array}{l}\text { Lack of field demonstrations with respect to blast disease } \\
\text { management }\end{array}$ & 79 & 83.75 \\
\hline 12 & Poor farmers- extension officers linkage & 60 & 98.75 \\
\hline 13 & Lack of trainings & 66 & 82.5 \\
\hline 14 & $\begin{array}{l}\text { Lack of awareness about the various schemes launched by } \\
\text { Governments for Aman and Aus paddy }\end{array}$ & 24 & 30 \\
\hline 15 & Lack of incentives to innovative farmers & 5 & 6.25 \\
\hline 16 & Poisonous and ill effect to cattle and human beings & 28 & 35 \\
\hline
\end{tabular}

3.1 Constraints in the Adoption of Plant Protection Measures for Management of Blast Disease of Rice

With regard to constraints in adoption of plant protection measures for management of blast disease of rice, the respondents expressed the following constraints as presented in Table 9. Climatic vagaries $(95 \%)$ were a major constrain in adoption of plant protection measures in paddy cultivation. About 90 per cent of the farmers expressed that the required pesticides are not available on time due to problem of transportation, lack of requiring facilities at nearby places $(95 \%)$. Further, the complicated name of chemicals or lack of knowledge about chemicals $(97.5 \%)$ was also a stumbling block in adoption of the management practices for blast disease of Rice. It has also been found that the farmers lack knowledge with regard to technology application (85\%) and hence face difficulty in disease management due to lack of knowledge about the number of sprays (83.75\%). High rate of inflation has impacted the price of the pesticides, labor cost etc. but in proportion to inflation the income of the farmers has not increased. Thus, due to high cost of the farm inputs including chemical pesticides $(60 \%)$, expensive labor $(83.75 \%)$, lack of finance $(55 \%)$, the farmers are unable to adopt the various plant protection measures for management of blast disease of rice. With respect to various extension activities which are a triggering factor in adoption of plant protection measures, it has been found that due to lack of proper demonstration and field visits $(98.75 \%)$, lack of training $(82.5 \%)$, lack of awareness about the various schemes launched by Governments for Aman and Aus paddy (30\%) there are gaps in adoption of plant protection measures. It has also been found that there was lack of incentives to innovative farmers (6.25\%) and due to poisonous and ill effect of the pesticides to cattle and human health, the adoption level is low.

\section{CONCLUSION}

The study reveals gap in the knowledge level about the plant protection measures for management of blast disease of rice and its adoption. Hence, there lies the vast scope for bridging this gap. It can be concluded from above findings that majority of the respondents belonged to medium level of knowledge and adoption regarding recommended plant protection measures against blast disease of rice in paddy cultivation. Though, the paddy is cultivated by all the farmers in the study area but 
their scientific knowledge about the recommended plant protection measures for management of blast disease of rice is still in infancy stage. There should be efforts to close the gaps among researchers; various organizations which focus on overall development of agriculture and policy traditionally focus on education, training, and/or dissemination of information within each separate arena. Even when such activities are effective, they have the potential to change only one group. Thus they generally fall far short of producing systemic change. Changing the system will require these groups working together to ask and answer the right questions and to jointly commit to implementation. Hence it is imperative that State Department of Agriculture, University of Agricultural Sciences, Agro chemical based companies and NGOs should make integrated and concerted extension efforts to provide required knowledge about recommended plant protection measures to the paddy growers and thereby motivating farmers for adoption.

\section{ACKNOWLEDGEMENT}

The authors wish to express their thanks to the farmers of Sundarban region of West Bengal for allowing to carry out the experiments. The study is a part of Ph.D. dissertation of the first author (Mrs. Sabita Nath) who is doing the programme at the Department of Plant Pathology, PalliSiksha Bhavana (Institute of Agriculture), VisvaBharati under the Supervision of the second author (Dr. Bholanath Mondal).

\section{COMPETING INTERESTS}

Authors have declared that no competing interests exist.

\section{REFERENCES}

1. Liu K, Zheng J, Chen F. Effects of washing, soaking and domestic cooking on cadmium, arsenic and lead bioaccessibilities in rice. Journal of the Science of Food and Agriculture. 2018;98(10):3829-3835.

DOI: $10.1002 /$ jsfa.8897

2. Mordor Intelligence. (2020). India Rice Market - Growth and Trends, Forecast To (2020 - 2025).

Available:https://www.mordorintelligence.c om/industry-reports/india-rice-market
3. Prasad, K. Pocket Book of Agricultural Statistics 2018. Directorate of Economics \& Statistics New Delhi: Government of India Ministry of Agriculture \& Farmers Welfare, Department of Agriculture, Cooperation \& Farmers Welfare; 2019.

4. Awotide BA, Karimov AA, Diagne A. Agricultural technology adoption, commercialization and smallholder rice farmers' welfare in rural Nigeria. Agricultural and Food Economics. 2016;4(3).

Available:https://doi.org/10.1186/s40100016-0047-8

5. Wilson RA, Talbot NJ. Under pressure: Investigating the biology of plant infection by Magnaporthe oryzae. Nature Reviews Microbiology. 2009;7:185-195.

DOI: https://doi.org/10.1038/nrmicro2032.

6. Ashkani S, Yusop MR, Shabanimofrad M, Harun AR, Sahebi M, Latif MA. Genetic analysis of resistance to rice blast: A study on the inheritance of resistance to the blast disease pathogen in an F3 population of rice. Journal of Phytopathology, 2015;163(4):300-309.

7. Sakulkoo W, Osés-Ruiz M, Oliveira Garcia E, Soanes DM, Littlejohn GR, Hacker C, Correia A, Valent B, Talbot NJ. A single fungal MAP kinase controls plant cell-tocell invasion by the rice blast fungus. Science. 2018;359(6382):1399-1403.

DOI: 10.1126/science.aaq0892

8. Musiime $\mathrm{O}$, Tenywa MM, Majaliwa MJG, Lufafa A, Nanfumba D, Wasige, John, Woomer PL, Kyondha M. Constraints to rice production in Bugiri district. African Crop Science conference proceedings. 2005;7:1495-1499.

9. Reshmy C. A study on sustainability of coconut and banana intercropping in kerala-An analysis. M.Sc. (Ag.) Thesis, University of Agricultural Sciences, Bengaluru, Karnataka, India; 1998.

10. Lakshmisha R. Impact of cashew demonstration on knowledge and adoption and yield levels of farmers in Dakshina Kannada district. M.Sc. (Ag.) Thesis, University of Agricultural Sciences, Bengaluru, Karnataka, India; 2000.

11. Babanna $T$. Information source consultancy and training needs of farmers in arecanut cultivation under Tungabhadra command area in Shimoga district. M. Sc. (Ag.) Thesis, University of Agricultural Sciences, Bengaluru, Karnataka, India; 2002. 
12. Raghavendra HN. A study on knowledge and adoption behaviour of arecanut farmers of South Canara district, Karnataka state. M.Sc. (Ag.) Thesis, University of Agricultural Sciences, Bengaluru, Karnataka, India; 1997.

13. Nityashree DA, Siddaramaiah. A comparative study of socio-psychological characteristics and adoption of improved practices of coffee among small and big coffee planters. Indian Coffee. 1993;7(8):711.

14. Balasubramani N. Study on knowledge and adoption behaviour of rubber growers in Belthangadi taluk of Dakshina Kannada district. M. Sc. (Ag.) Thesis, University of Agricultural Sciences, Bengaluru, Karnataka, India; 1997.

15. Vasanthakumar MP. A study on knowledge, adoption and economic performance of coffee growers in Virajpet Taluk of Coorg district. M.Sc. (Ag.) Thesis, University of Agricultural Sciences, Bengaluru, Karnataka, India; 2000.

16. Manjunath T. A study on knowledge and adoption of plant protection measures by paddy growers of Raichur district. M.Sc. (Ag.) Thesis, Universityof Agricultural Sciences, Dharwad, Karnataka, India; 2010.

(c) 2020 Nath et al.; This is an Open Access article distributed under the terms of the Creative Commons Attribution License (http://creativecommons.org/licenses/by/4.0), which permits unrestricted use, distribution, and reproduction in any medium, provided the original work is properly cited.

Peer-review history:

The peer review history for this paper can be accessed here: http://www.sdiarticle4.com/review-history/63156 